\title{
IMPLEMENTASI STRATEGI PROMOSI PRODUK DALAM PROSES KEPUTUSAN PEMBELIAN MELALUI DIGITAL MARKETING SAAT PANDEMI COVID'19
}

\author{
Putri Lestari \\ Universitas Islam Negeri Sunan Ampel Surabaya \\ putri08iman@gmail.com \\ Muchammad Saifuddin* \\ Universitas Islam Negeri Sunan Ampel Surabaya \\ saifuddin@uinsby.ac.id
}

\begin{abstract}
Abstrak
Penelitian ini adalah penelitian yang berjudul Implementasi Strategi Promosi Dalam Proses Keputusan Pembelian Melalui Digital Marketing Saat Pandemi Covid'19. Penelitian ini dilatarbelakangi oleh adanya pandemi covid'19 yang merupakan hambatan bagi perusahaan dalam memasarkan produk yang diproduksi oleh perusahaan. Tujuan dari penelitian ini adalah memberikan gambaran mengenai bentuk promosi yang dilakukan oleh perusahaan disaat pandemi covid'19 yang tidak bisa diprediksi berakhirnya pandemi covid'19 tersebut. Penelitian ini merupakan penelitian kualitatif deskriptif yaitu dengan menggunakan literatur atau studi pustaka yang terfokus untuk menjelaskan hasil penelitian yang diperoleh oleh peneliti. Hasil dari penelitian ini adalah memberikan gambaran mengenai hubungan promosi melalui digital marketing dengan keputusan pembelian pada saat pandemi covid'19.
\end{abstract}

Kata kunci: Digital Merketing, Keputusan Pembelian, Pemasaran, Promosi

\section{PENDAHULUAN}

Dalam bisnis yang terjadi pada saat ini, banyak hal-hal yang bisa mempengaruhi pembelian suatu produk, baik disebabkan oleh faktor internal perusahaan seperti manajemen strategi (promosi) yang diterapkan perusahaan maupun dari lingkungan eksternal perusahaan seperti peraturan pemerintah dan kebijakan pemerintah terlebih lagi pada masa sekarang terdapat wabah covid'19 yang membuat seluruh aspek perekonomian tidak tertata dan berantakan. Dalam situasi yang seperti ini khususnya pada saat pandemi covid'19, banyak perusahaan-perusahaan yang mau tidak mau harus melakukan perombakan mengenai manajemen yang ada di dalam perusahaan itu sendiri seperti halnya dalam perombakan pada strategi promosi produk yang digunakan oleh perusahaan yang dinilai kurang efektif digunakan pada saat pandemi covid'19 yang semakin parah.

Promosi produk merupakan salah satu cara yang dilakukan oleh perusahaan yang bertujuan untuk mendobrak penjualan produk yang telah dihasilkan. Promosi adalah cara untuk menginformasikan, merujuk, dan mengingatkan kosumen secara langsung maupun tidak langsung tentang suatu produk atau brand yang dijual. (Irna Fitri, 2016). Selain untuk meningkatkan penjualan produk, promosi juga memiliki tujuan-tujuan tertentu yaitu untuk menyampaikan informasi, memposisikan produk, dan memberikan nilai tambah dari produk.

Promosi produk secara otomatis akan memaparkan informasi-informasi mengenai produk baik secara umum maupun informasi khusus. Biasanya informasi yang dipaparkan dalam promosi adalah keterangan produk seperti kegunaan produk, kelebihan dan kekurangan produk. Selain memberikan informasi mengenai produk, informasi yang dipaparkan dalam promosi juga 
dibuat semenarik mungkin untuk memberikan pengaruh kepada konsumen khususnya pangsa pasar yang bertujuan untuk menarik perhatian konsumen dalam melakukan pembelian produk yang ditawarkan atau dipromosikan. Dalam proses promosi produk selain untuk memberikan informasi produk, promosi juga bertujuan untuk memposisikan produk. Dalam hal ini, promosi bisa dikatakan berhasil jika kegiatan promosi mampu menempatkan produk menjadi brand of mine.

Dalam keadaan pandemi covid'19, banyak perusahaan-perusahaan yang mengalami kerugian baik materiil maupun non materiil dan terdapat juga beberapa perusahaan dan UKM- UKM yang melakukan PHK secara besar-besaran guna menyelamatkan perusahaan dan ada juga yang mengalami gulung tikar. Dalam hal ini dibutuhkan strategi promosi yang tepat untuk menyikapi keadaan yang semakin memburuk. Pada saat ini, perusahaan yang berusaha bertahan dalam situasi yang menyulitkan tetap berupaya untuk "bagaimana caranya agar produk yang sudah diproduksi bisa terjual" pada masyarakat. Hal ini bertujuan minimal mampu meminimalisir kerugian yang ditanggung oleh perusahaan yaitu kerugian dari sisi beban yang telah dikeluarkan untuk melakukan produksi tersebut.

Perusahaan melakukan strategi promosi yang memiliki peluang besar untuk menjual produknya seperti contoh melalui digital marketing, digital marketing diharapkan perusahaan sebagai jalan keluar yang tepat dalam masa pandemi covid'19. Perusahaan memiliki penilaian mengenai digital marketing mengenai keuntungan-keuntungan yang bisa didapat oleh perusahaan dan juga kenyamanan bagi konsumen. Selain keuntungan yang diperoleh perusahaan mengenai digital marketing yaitu membantu perusahaan meminimalkan beban pemasaran karena perusahaan hanya menggunakan media onlie dalam mempromosikan produknya, konsumenpun memiliki keuntungan yaitu konsumen tidak perlu keluar rumah untuk melihat produk-produk yang dicari sehingga konsumen sedikit banyak tidak perlu khawatir terpapar virus covid'19. Digital marketing sendiri adalah upaya yang dilakukan dalam hal pemasaran dengan menggunakan perangkat yang terhubung dengan internet denagn beragam strategi dan media digital dengan tujuan yaitu perusahaan bisa tetap berhubungan dengan konsumen melalui saluran komunikasi online. (Andi Gunawan Chakti, 2019). Sebagai contoh beberapa akses dalam digital marketing yaitu website, blog, media sosial (instagram, whatsapp, line), interactive audio vidio (youtube, vidio), interactive audio (podcast, soundcloud), dan display ads.

\section{METODE PENELITIAN}

\section{Jenis Penelitian}

Jenis penelitian yang digunakan dalam penelitian ini adalah penelitian kualitatif deskriptif yaitu dengan menggunakan literatur atau studi pustaka yang terfokus untuk menjelaskan hasil penelitian yang diperoleh oleh peneliti.

\section{Metode Pengumpulan Data}

Metode yang digunakan dalam penelitian ini adalah metode pengambilan data sekunder. Pengambilan data sekunder penelitian ini melalui buku-buku mengenai pemasaran, skripsi, dan jurnal-jurnal ilmiah serta website yang relevan dengan penelitian ini dan memiliki variabel dependen dan independen yang sama dengan judul yang telah dipilih oleh peneliti.

\section{KAJIAN TEORI}

\section{Konsep-konsep Pemasaran}

Pemasaran merupakan suatu proses dan manajerial yang membuat individu atau kelompok mendapatkan apa yang diinginkan dan dibutuhkan dengan menciptakan, menawarkan, dan mempertukarkan produk yang bernilai kepada pihak lain atau segala kegiatan yang menyangkut 
penyampaian produk atau jasa mulai dari produsen sampai dengan konsumen. Sasaran dari pemasaran ini yaitu menarik pelanggan baru dengan menjanjikan nilai superior, menetapkan harga yang menarik, mendistribusikan produk atau jasa dengan mudah, mempromosikan secara efektif serta mempertahankan pelanggan yang sudah ada dengan tetap memegang prinsip yaitu kepuasan pelanggan. (Agustina Shinta, 2011).

Konsep pemasaran menyatakan bahwasanya untuk meraih tujuan organisasi adalah menjadi lebih efektif dari pada para pesaing dalam memadukan kegiatan pemasaran guna menetapkan dan memuaskan kebutuhan dan keinginan sasaran pemasaran. Dalam hal ini, konsep pemasaran berfokus pada gagasan untuk memuaskan kebutuhan konsumen melalui produk dan segala sesuatu yang berkaitan dengan penciptaan, pertukaran, pengiriman, dan pengonsumsian produk yang ditawarkan.

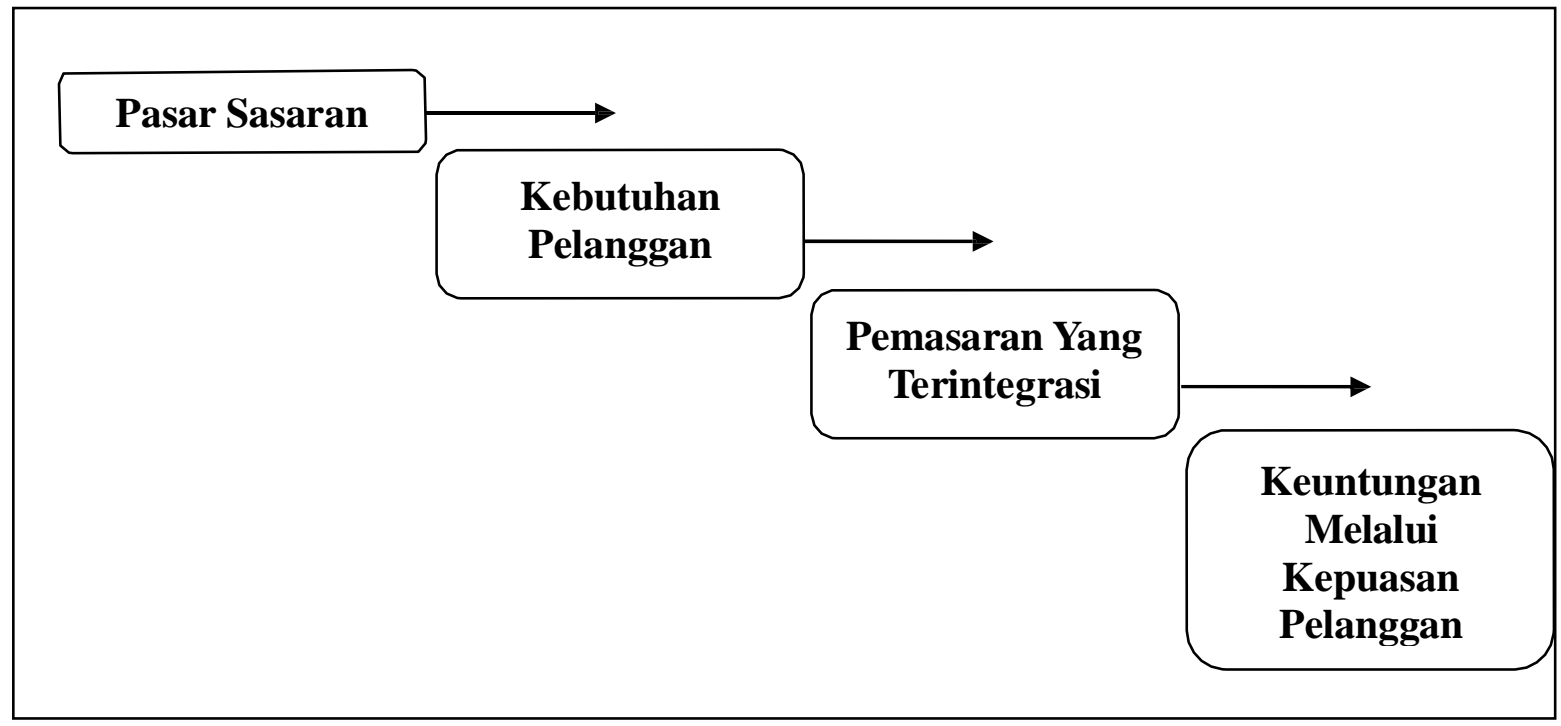

Gambar 1. Konsep dasar Pemasaran

Dari keempat pilar konsep dasar pemasaran, pemasaran disini berorientasi dari luar kedalam. Konsep ini dimulai dengan mendefinisikan pasar dengan baik, memusatkan pertahian kepada kebutuhan pelanggan, memadukan seluruh kegiatan yang akan mempengaruhi pelanggan dan menghasilkan laba melalui pemusatan pelanggan. (M. Anang Firmansyah, 2019).

Sebelum menetapkan pasar sasaran, perusahaan harus mengelompokkan atau membagi pasar menjadi kelompok-kelompok pembeli yang berbeda dan mungkin memerlukan produk dan strategi pemaaran yang berbeda dan hal ini yang dinamakan segmentasi pasar. Lankah selanjutnya yaitu menetapkan pasar sasaran, setelah menetapkan pasar sasaran berarti mengevaluasi keefektifan setiap segmen dan kemudian memilih salah satu dari segmen pasar atau lebih untuk dilayani. Cara untuk menetapkan pasar sasaran yaitu dengan cara mengembangkan ukuran-ukuran dan daya tarik segmen dan kemudian memilih segmen sasaran yang diinginkan. Terdapat dua kegiatan yang digunakan dalam menetapkan pasar sasaran yaitu:

1. Evaluasi segmen pasar

a) Ukuran dan pertumbuhan segmen seperti pendapatan dan gaya hidup dari setiap segmen.

b) Struktur segmen yang menarik yang dilihat dari segi profitabilitas, ancaman dari produk pengganti, dan ancana dari pesaing yang kuat dan agresif.

c) Sasaran dan sumberdaya yang dimiliki seperti ketersediaan sumberdaya manusia. 
2. Memilih segmen

Memilih segmen yaitu berarti menentukan satu atau lebih segmen yang memiliki nilai tinggi bagi perusahaan kemudian menentukan segmen mana dan berapa banyak yang bisa dilayami oleh perusahaan. (Kasmir, 2018).

Selanjutnya adalah kebutuhan pelanngan, kebutuhan pelanggan pada dasarnya adalah sama dengan kebutuhan manusia pada umumnya. Dalam hal ini, kebutuhan pelanggan dapat diklasifikasikan menurut bebarapa aspek yaitu menurut tingkat kepentingan, sifatnya, waktu dan subjek. Menurut tingkat kepentingannya, kebutuhan pelanggan dibedakan menjadi tiga yaitu kebutuhan primer (kebutuhan utama), sekunder (kebutuhan pelengkap), dan tersier (kebutuhan akan barang mewah). Menurut sifatnya, kebutuhan pelanggan bisa dibagi menjadi dua ytiu kebutuhan jasmani (kebutuhan yang berkaitan dengan fisik pelanggan) misalnya makanan dan kebutuhan rohani (kebutuhan yang berkaitan dengan psikologis pelanggan) misalnya liburan. Menurut waktunya, kebutuhan pelanggan dibagi menjadi dua yaitu kebutuhan sekarang 9kebutuhan yang tidak bisa ditunda) dan kebutuhan masa depan (kebutuhan yang tidak mendesak segera terpenuhi). Dan menurut subjeknya, kebutuhan pelanggan bisa digolongkan menjadi kebutuhan individu dan kebutuhan kolektif atau kelompok. (Amrida, Armiati, dan Leo, 2016).

Terdapat dua tema kunci dalam pemasaran yang terintegrasi yaitu pertama, banyak aktivitas pemasaran yang berbeda dalam mengomunikasikan dan menyampaikan nilai. Kedua, ketika proses pengoordinasian, saat itu pula aktivitas pemasaran memaksimalkan efek gabungannya. (Miguna, dan Agni, 2020). Konsep pemasaran yang terakhir yaitu keuntungan melalui kepuasan pelanggan, hal ini bermaksud jika kepuasan pelanggan terpenuhi atau perusahaan bisa memenuhi ekspektasi pelanggan melalui produk yang ditawarkan maka kepuasan tersebut adalah keuntungan yang diperoleh perusahaan. Hal ini sangat berbeda dengan penjualan, penjualan hanya akan berfokus pada keuntungan materiil (diukur dengan uang) tetapi yang dimaksud keuntungan dalam pemasaran adalah kepuasan konsumen (user) yang timbul dari produk. Hal ini disebabkan selain untuk menyenangkan konsumen produknya, kepuasan konsumen akan memberikan kehidupan bagi perusahaan dan konsumen menjadi percaya terhadap perusahaan tersebut. Bisa disingkat bahwa, penjualan hanya berfokus pada tujuan jangka pendek perusahaan dan sebaliknya, pemasaranlah yang berorientasi pada tujuan jangka panjang perusahaan.

Pemasaran merupakan suatu proses dan manajerial yang membuat individu atau kelompok mendapatkan apa yang diinginkan dan dibutuhkan dengan menciptakan, menawarkan, dan mempertukarkan produk yang bernilai kepada pihak lain atau segala kegiatan yang menyangkut penyampaian produk atau jasa mulai dari produsen sampai dengan konsumen. Sasaran dari pemasaran ini yaitu menarik pelanggan baru dengan menjanjikan nilai superior, menetapkan harga yang menarik, mendistribusikan produk atau jasa dengan mudah, mempromosikan secara efektif serta mempertahankan pelanggan yang sudah ada dengan tetap memegang prinsip yaitu kepuasan pelanggan. (Saifuddin, 2013).

\section{Promosi Produk}

Kegiatan promosi biasanya merupakan komponen prioritas dalam manajemen pemasaran. Dengan adanya promosi maka konsumen akan mengetahui perusahaan meluncurkan produk baru yang akan mempengaruhi konsumen untuk melakukan pembelian. Kegiatan promosi merupakan kegiatan yang digunakan perusahaan untuk menyebarkan informasi untuk disebarkan dan ditujukan kepada konsumen. (Warnadi dan Aris Triyono, 2019). Promosi diartikan sebagai koordinasi dari keseluruhan upaya yang dimulai pihak penjual (produsen) untuk membangun berbagai saluran informasi dan persuasi untuk menjual barang dan jasa atau memperkenalkan suatu gagasan. Disisi lain, promosi juga merupakan arus informasi atau persuasi satu arah yang 
dibuat untuk mengarahkan seseorang atau organisasi kepada tindakan yang menciptakan pertukaran dalam pemasaran. (Resty Avita Haryanto, 2013).

Dalam hal ini, jenis promosi biasanya menjadi salah satu alasan konsumen membeli sebuah produk. Dalam hal ini, terkadang hal-hal yang dipaparkan dan dijanjikan di dalam produk hanya sebatas omong kosong tetapi tidak semua produk melakukan promosi seperti yang demikian. Untuk menyikapi hal-hal yang tidak diinginkan, kosumen sangat berhati-hati dalam membeli produk terlebih konsumen akan menganalisa dan mencari informasi mengenai produk terlebih dahulu sebagai cara menyikapi adanya promosi yang tidak jelas dan promosi yang dapat merugikan konsumen. dalam hal ini, biasanya kalimat yang digunakan dalam promosi merupakan kalimat persuasif yang bertujuan untuk mengajak konsumen untuk membeli produk yang ditawarkan.

\section{Keputusan Pembelian}

Keputusan membeli adalah kegiatan pemecahan masalah yang dilakukan individu dalam pemilihan alternatif perilaku yang bisa dipilih dan dianggap sebagai tindakan yang paling tepat dalam membeli dengan terlebih dahulu dengan melalui tahapan proses pengambilan keputusan. Dalam proses sebelum memutuskan untuk membeli, ada beberapa tahapan dalam keputusan pembelian yaitu:

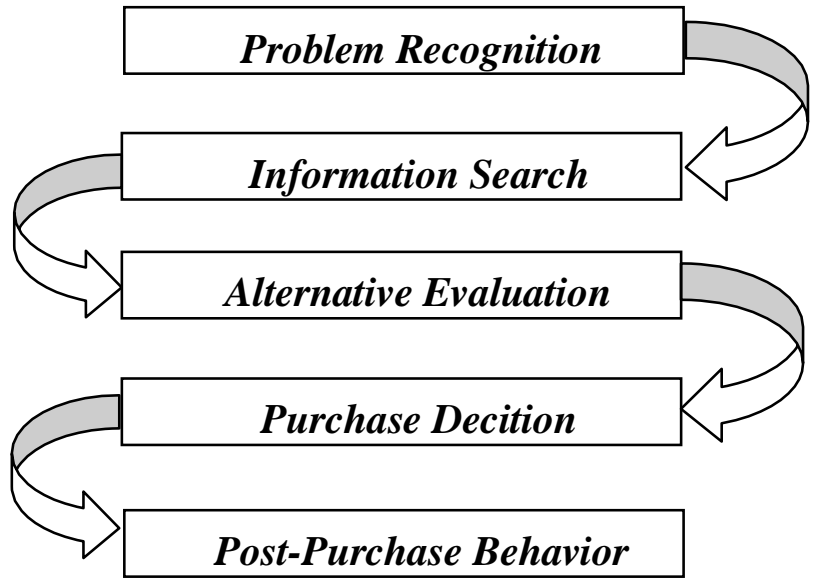

Gambar 2. Perilaku konsumen dalam mengambil keputusan pembelian

1. Pengenalan masalah (Problem Recognition)

Pada tahapan yang pertama, sebelum konsumen memutuskan untuk membeli suatu produk, konsumen akan secara alami merasa produk apa yang mereka iningkan atau butuhkan. Setelah konsumen mengenali atau mengerti produk apa yang mereka butuhkan maka konsumen akan mencari karakteristik dari produk tersebut mulai dari keunggulan, kelemahan, apakah produk ini sesuai dengan apa yang dibutuhkan dan apakah produk ini memberikan dampak yang positif bagi konsumen.

\section{Pencarian informasi (Information Search)}

Setelah konsumen menemukan produk apa yang dibutuhkan, secara otomatis konsumen akan melakukan proses pencarian informasi mengenai produk tersebut baik secara aktif maupun pasif. Dalam hal ini, yang dimaksud dengan pencarian informasi secara aktif yaitu dengan melakukan kunjungan ke toko-toko dengan tujuan membuat perbandingan mengenai harga maupun kualitas produk. Sedangkan untuk pencarian 
informasi secara pasif, konsumen akan mendapatkan informasi dari koran, televisi, radio, internet, dan majalah. Setelah konsumen memperoleh segala informasi yang dibutuhkan mengenai produk yang ingin dibeli, konsumen akan mempertimbangkan kembali mengenai produk tersebut dan dibantu dengan informasi-informasi yang didapatkan.

\section{Evaluasi alternatif (Alternative Evaluation)}

Dalam hal ini, setelah menemukan informasi yang dibutuhkan mengenai suatu produk maka konsumen akan melakukan evaluasi mengenai alternatif yang tersedia pada produk dari informasi yang didapatkan. Pada hakikatnya, evaluasi merupakan keyakinan dan sikap yang mempengaruhi perilaku pembelian konsumen. Terdapat dua tahapan dalam proses evaluasi alternatif yaitu menetapkan tujuan pembelian dan menilai dan mengadakan seleksi terhadap alternatif pembelianberdasarkan tujuan pembeliannya.

\section{Keputusan pembelian (Purchase Decition)}

Setelah ketiga tahap tersebut telah dilakukan, maka selanjutnya adalah memberikan keputusan apaka konsumen akan membeli atau tidak dilihat dari jenis produk, bentuk produk, merek, penjual dan kualitasnya. Jika setelah knsumen melakukan pembelian suatu produk dan konsumen merasa puas maka tidak menutup kemungkinan konsumen akan melakukan pembelian lagi terhadap produk tersebut.

\section{Perilaku pasca pembelian (Post-Purchase Behavior)}

Dalam tahapan yang terakhir, setelah konsumen membeli suatu produk maka secara otomatis konsumen bisa menggolongkan tingkat kepuasan yang dirasakan. Berdasarkan tingkat kepuasan tersebut konsumen akan melakukan lagi perbandingan mengenai produk yang dibeli dengan produk sejenis yang lain. Hal ini bisa berkaitan dengan harga produk, kualitas produk, manfaat produk dan kecocokan produk dengan konsumen. (M. Anang Firmnaysah, 2018).

\section{Digital Marketing}

Digital Marketing adalah bentuk pemasaran modern sekaligus merupakan harapan baru dan

dobrakan baru bagi perusahaandan diharapkan memberikan dapak positif bagi perusahan. Digital marketing memungkinkan pengiklanan berkomunikasi langsung dengan konsumen potensial tanpa terhalang oleh waktu dan lokasi geografis. Salah satu cara terbaik dalam mengatasi dan meminimalisir kekacauan dan berkomunikasi langsung dengan pelanggan yaitu dengan pemasaran digital (digital marketing). (Mahalaxmi dan Ranjth, 2016). Sedangkan menurut Saifuddin (2020) Pemasaran digital adalah sebuah penggunaan teknologi elektronik terutama dalam bentuk teknologi informasi untuk melakukan segala proses bisnis termasuk didalamnya kegiatan jual beli produk, jasa dan informasi, meningkatkan permintaan, melayani pelanggan dengan sentuhan digital.

Sehingga dapat disimpulkan bahwasanya digital marketing merupakan salah satu kegiatan promosi dan pencarian pasar melali media digital secara online dengan memanfaatkan berbagai saranaseperti halnya jejaring sosial. Hal ini disebabkan karena dunia maya tidak hanya mampu menghubungkan orang dengan perangkat melainkan juga orang dengan orang lain di seluruh dunia. 


\section{PEMBAHASAN}

Pada beberapa kajian literatur yang ada khususnya jurnal-jurnal ilmiah, terdapat beberapa pembahasan dan analisa mengenai implementasi strategi promosi dalam proses keputusan pembelian dan mengenai digital marketing. Beberapa diantaranya adalah, pertama yaitu penelitian yang dilakukan oleh Bagas Aji Pamungkas dan Siti Zuhroh dengan judul penelitian yaitu Pengaruh Promosi Di Media Sosial Dan Word Of Mouth Terhadap Keputusan Pembelian (Studi Kasus Pada Kedai Bontacos Jombang). Hasil dari penelitian ini adalah promosi menggunakan media sosial dan word of mouth secara arsial dan simultan berpengaruh terhadap keputusan pembelian, dan strategi promosi menggunakan media sosial dinilai menjadi strategi pemasaran yang cukup efektis untuk Kedai Bontacos dan didukung dengan word of mouth yang positif yang mampu menarik konsumen untuk melakukan pembelian di kedai bontacos.

Web Series Marketing Communication Trough Digital Traveloka adalah penelitian yang dilakukan oleh Eka Prastianto, Farhan Julian, dan Dini Safitri. Penelitian ini membahas mengenai optimalisasi media sosial sebagai media komunikasi pemasaran digital Traveloka sebagai aplikasi layanan pedukung bisnis travel di Indonesia. Hasil penelitian ini adalah adanya pasar online era digital banyak memiliki sisi positif yaitu bisa lebih dekat dengan konsumen dan lebih cepat dalam waktu, dan dengan cepat mempromosikan atau memperkenalkan produk kepada publik, ketiadabatasan pasar untuk menjangkau seluruh pelosok dunia yang terhubung dengan interner dan ketepatan serta kecepatan layanan menjadi kebutuhan utama konsumen di era globalisasi.

Selanjutnya adalah Strategi Pemasaran Bisnis Kuliner Menggunakan Influencer Melalui Media Sosial Instagram yang diteliti oleh Made Resta Handika, Agus Fredy Maradona, dan Gede Sri Darma. Terdapat beberapa kesimpulan yang diambil peneliti dalam peneitian yang dilakukan yaitu peneliti merumuskan alasan-alasan yang mendasari "pengalihan strategi pemasaran dari cara konvensional yang beralih ke strategi pemasaran instagram marketing". Alasan pertama pengalihan strategi pemasaran ini karena kemajuan teknologi dan konsumen lebih condong menggunakan sosial media instagram. Alasan kedua yaitu dengan menggunakan sosial media marketing (instagram) dapat menekan cost dalam pembiayaan marketingnya. Alasan ketiga yaitu dengan memanfaatkan influencer lebih mampu meningkatkan pemasaran instagram dan berdampak positif bagi kemajuan bisnis.

Penelitian yang dilakukan oleh Afan Nurcahyo mengenai Peran Digital Marketing dan Harga Kompetitif Terhadap Keputusan Berlangganan Indihome merupakan penelitian yang menganalisa peran digital marketing terhadap keputusan berlangganan Indihome. Penelitian ini memberikan hasil dimana pemasaran digital (digital marketing) berpengaruh signifikan terhadap keputusan pembelian. Untuk memperjelas alasan digital marketing memiliki pengaruh yang signifikan terhadap keputusan pembelian yaitu dengan adanya digital marketing, pelanggan dapat memperoleh informasi tentang harga, promo, keunggulan, fasilitas, dan persyaratan dari laman web resmi Indihome Fiber melalui situs pencarian, iklan Indihome Fiber di internet dan sitis web lainnya, melalui jejaring sosial seperti facebook, email, melalui media sosial whatsapp maupun telegram.

\section{Promosi Produk Melalui Digital Marketing Pada Saat Pandemi Covid'19}

Covid'19 merupakan pandemi yang menyerang seluruh negara di dunia dan terus menyebar terutama juga Indonesia, pada saat ini (pandemi corona'19) seluruh masyarakat Indonesia wajib melakukan social distancing (jaga jarak) dan melakukan PSBB tanpa terkecuali begitupun perusahaan. Dampak dari kebijakan pemerintah sebagai upaya untuk memutus rantai covid'19, perusahaan dan masyarakat sangat dirasa dampaknya. Perusahaan hanya bisa memprogram kegiatan dari gadget, sebagian tim produksi perusahaan terpaksa dirumahkan sampai waktu yang 
tidak bisa dipastikan karena pandemi ini masih belum dipastikan kapan akan berakhir. Bagi masyarakat, pandemi ini berdampak langsung pada pendapatan yang dulunya berkecukupan menjadi kekurangan karena ketiadaan pemasukan tetapi kebutuhan akan barang tidak bisa dikurangi dan konsumen juga kesulitan dalam upaya untuk memperoleh barang yang dibutuhkan.

Menyikapi kondisi seperti ini perusahaan harus melakukan perombakan strategi pemasaran sebagai upaya untuk menjawab masalah konsumen dalam kesulitan mendapatkan produk yang dibutuhkan. Strategi yang dimaksud perusahaan merupakan strategi promosi melalui digital marketing. Digital marketing merupakan cara promosi dengan memanfaatkan kegunaan gadged seperti aplikasi-aplikasi, web-web yang bisa menghubungkan antara konsumen dan produsen (perusahaan). Dalam melakukan promosi, perusahaan bisa melakukan promosi melalui lima saluran dalam digital marketing yaitu mealui. (I Gede A, 2018):

a. Website

Website atau web merupakan halaman informasi yang disediakan melalui internet yang dapat diakses diseluruh penjuru dunia selama masih terkoneksi dengan internet.

b. Media sosial

Media sosial atau sosial media merupakan media online yang penggunanya bisa berbagi, berpartisipasi, dan bisa juga menciptakan isi konten teks, gambar, vidio dan streaming online. Dalam hal ini, media sosial yang populer digunakan yaitu facebook, instagram, twitter, dan youtube. Selain berfungsi menjadi perantara untuk chatting, sharing vidio dan mencari teman, media sosial ini juga bisa digunakan dalam melakukan promosi dengan mengupload produk yang ditawarkan.

c. Online advertising

Online advertising merupakan iklan yang dibuat secara online atau website yang menarik pelanggan. Dengan adanya media online ini, perusahaan lebih mudah dalam melakukan promosi dengan cara menaruh iklan di website-website yang menyediakan tempat pasang iklan.

d. Forrum discussion

Forrum discussion merupakan kumpulan forum yang secara online yang memuat data, gambar, animasi, suara, vidio yang tergabung dan terhubung dngan jaringan.

e. Mobile application

Mobile application merupakan aplikasi mobile yang didesain khusus untuk perangkat smartphone dan tablet. Seiring dengan berkembangnya mobile semua informasi bisa didapatkan dari mobile dan transaksi bisa dilakukan secara mobile. Dengan keadaan system yang terintegrasi dan terupdate secara real time baik konten, gambar, animasi, vidio maupun suaraakan bisa mempermudah dalam mempromosikan produk secara digital. Disisi lain, hal ini akan bisa memanjakan konsumen untuk mencari produkproduk yang diinginkan dan hal ini juga bisa memangkas beban operasional yang ditanggung oleh perusahaan.

\section{KESIMPULAN}

Perubahan strategi promosi yang dulunya konvensional menjadi promosi digital marketing yang dilakukan oleh perusahaan disaat pandemi covid'19 merupakan hal yang positif. Dalam hal ini selain memberikan manfaat bagi konsumen juga memberikan manfaat bagi perusahaan. Manfaat ini meliputi kepraktisan dalam melakukan pemasaran, memperkecil beban operasional perusahaan khususnya pada beban yang dianggarkan untuk proses promosi yang seharusnya, lebih cepat menanggapi konsumen baik segala sesuatu yang berkaitan dengan konsumen. 


\section{DAFTAR PUSTAKA}

Astuti, M., Agni, R. A. (2020). Pengantar Manajemen Pemasaran. Yogyakarta: CV. Budi Utama. Firmanysah, M. A. (2018). Perilaku Konsumen (Sikap dan Pemasaran). Yogyakarta: CV. Budi Utama.

Chakti, A. G. (2019). The Book Of Digital Marketing. Makasar: Celebes Media Perkasa. Pamungkas, B. A., dan Siti Z. (2016). Pengaruh Promosi Di Media Sosial Dan Word Of Mouth Terhadap Keputusan Pembelian (Studi Kasus Pada Kedai Bontacos Jombang). Jurnal Komunikasi, x(2), 145.

Firmansyah, M. A. (2019). Pemasaran (Dasar dan Konsep). Pasuruan: Qiara Media. Shinta, A. (2011). Manajemen Pemasaran. Malang: Universitas Brawijaya Press.

Fitri, I. (2016). Analisis Promosi Penjualan Online, Harga, Kepercayaan, Dan Kemudahan Terhadap Keputusan Pembelian Online Ceker Brontak (Studi Pada Ceker Brontak kota Bandar Lampung). Diambil dari digilib.unila.ac.id

Handika, M. R., Agus F. M., dan Gede S. D. (2018). Strategi Pemasaran Bisnis Kuliner Menggunakan Influencer Melalui Media Sosial Instagram. Jurnal Manajemen dan Bisnis, 15(2), 192.

Haryanto, R. A. Strategi Promosi, Kualitas Produk, Kualitas Layanan terhadap Kepuasan Pelanggan Pada Restoran MCDonald's Manado. Jurnal Emba, 1(4), 1466.

Mahalaxmi, K. R., dan Ranjith, P. (2016). A Study on Impact of Digital Marketing in Customer Purchase Decision in Trichy. International Journal fot Innovative Research in Science and Technoligy, 2(10), 332-338.

Nurcahyo, A. (2018). Peran Digital Marketing dan Harga Kompetitif Terhadap Keputusan Berlangganan Indihome. Jurnal Manajemen dan Bisnis, 1(1), 15.

Kasmir. (2018). Pemasaran Bank. Jakarta: Kencana.

Prastinto, E., Farhan J., dan Dini S. (2019). Web Series Marketing Communication Trough Digital Traveloka. Jurnal Ilmu Komunikasi, 8, 16-17.

Saifuddin, M. (2013). Pengaruh Jenis Endorser dan Brand Name terhadap Sikap Atas Iklan, Sikap Atas Merk dan Niat Pembelian pada Produk High dan Low Involvement. Jurnal Ekonomi dan Bisnis Airlangga (JEBA), 23(3).

Saifuddin, M. (2020). Strategi Peningkatan Ekonomi Lembaga Sosial Dengan Memanfaatkan Aplikasi Pemasaran Berbasis Android (Studi kasus pada unit bisnis kidpreneuer di Yayasan AL MADINA Surabaya).

Wardani, Aris, T. (2019). Manajemen Pemasaran. Yogyakarta: CV. Budi Utama. Asriel, A. S., Armiati, Leo, F. (2016). Manajemen Kantor. Jakarta: Kencana.

Warmayana, I. G. A. K. (2018). Pemanfaatan Digital Marketing dalam Promosi Pariwisata pada Era Industri 4.0. Jurnal Pariwisata Budaya, 3(2), 81-92. 